If you wish to cite this pre-publication paper, please use the following format: lan Forrest, 'Medieval History and Anarchist Studies', forthcoming in Anarchist Studies, 29:1 (Spring 2021).

\title{
Medieval history and anarchist studies
}

Abstract: Medieval history and anarchist studies have a great deal to offer one another, but there is very little intellectual traffic between the two fields. This paper encourages historians to deploy anarchism as an approach to historical research akin to Marxist or feminist historiography, so that 'anarchist history' can move beyond the history of the modern anarchist movement and become a radical new way of studying and learning from the human past. Recent developments in anthropology and archaeology are offered as examples of how this might happen. Medieval history would benefit from the development of an anarchist approach to questions of ungoverned spaces, domination and inequality, and the growth of states and institutions. Anarchist studies would benefit from greater awareness of recent research in medieval history, much of which is relevant to anarchist interests.

Keywords: medieval history, feminism, anthropology, archaeology 
If you wish to cite this pre-publication paper, please use the following format: lan Forrest, 'Medieval History and Anarchist Studies', forthcoming in Anarchist Studies, 29:1 (Spring 2021).

\section{Medieval history and anarchist studies}

Not only the past but also the future, not only the future but also the past

Ursula Le Guin, The Dispossessed

This paper makes two proposals: that an anarchist perspective has a lot to offer the study of medieval history, and that medieval history has, in turn, a lot to offer anarchist studies. There has been very little intellectual traffic between the two fields, with medievalists rarely looking to anarchist ideas for inspiration, and anarchist scholars being by-and-large unaware of work by medieval historians that is relevant to their concerns. I do not propose to devote much space to considering why this is, preferring to describe the future benefits that greater contact between these fields could bring to each, but two things seem clear: first, despite the historical interests of many anarchist writers, anarchist studies is - at the moment - primarily a sub-field of political science, a discipline whose fondness for theory and severely-truncated timelines makes many historians wary to say the least; second, anarchists who are historians have tended to concentrate rather narrowly on the history of anarchist movements and thinkers.

Although I have always been attracted to anarchist ideas, and my historical work on institutions and the people in the 'late medieval' period (roughly 1100 to 1500) has come to be more and more informed by an anarchist perspective, I have not explicitly positioned myself in this way, at least not in print, until now. My academic anarchism 
If you wish to cite this pre-publication paper, please use the following format: lan Forrest, 'Medieval History and Anarchist Studies', forthcoming in Anarchist Studies, 29:1 (Spring 2021).

does not derive from extensive reading in the theories and interpretations of classical anarchism, but from the ways in which my early exposure to environmental anarchism and some of the currents that would feed into so-called post-anarchism acted as a filter through which I absorbed my education as a historian, and as an inoculation against the elitist myopia and social reductionism that I found in much of the social and political theory that otherwise interested me. The present essay is therefore a personal attempt to think through some of the potential for and implications of an anarchist history, specifically related to my own field of medieval history.

I will draw upon some findings from my own research, while illustrating the potential fruitfulness of collaboration by noting some current trends in the writing of medieval history. I will also situate the potential for an anarchist historiography alongside recent developments in anthropology and archaeology, disciplines that offer complementary ways of studying the past. Although there is much common ground between the three disciplines, historians, and medieval historians in particular, have something distinctive to add to the development of academic anarchism as a significant interpretative approach to the study of human experience and potential.

But, you may be asking, isn't there lots of anarchist history already? After all, anarchists are often very well-versed in the history of their own movement, and a number of important anarchist writers have taken an explicitly historical approach to social questions. Among the founding intellects of nineteenth-century anarchism, Peter Kropotkin is especially known for the historical case studies from which he elaborated 
If you wish to cite this pre-publication paper, please use the following format: lan Forrest, 'Medieval History and Anarchist Studies', forthcoming in Anarchist Studies, 29:1 (Spring 2021).

his model of mutual aid, in particular what he termed the 'free cities' of medieval Europe. The same phenomenon was also central to the historical imagination of Rudolf Rocker, whose 1938 book Nationalism and Culture similarly drew upon a romantic reading of certain aspects of medieval history. ${ }^{1}$ This enervating interest in the premodern past was then echoed in many politically-sympathetic histories of anarchism, notably George Woodcock's Anarchism of 1962, which claimed the English peasants' revolt of 1381 and Anabaptist Münster in the years 1534-35 as precursors of the modern movement, and in Peter Marshall's ambitious 1992 history of anarchism, Demanding the Impossible. ${ }^{2}$

Such histories of anarchism are valuable in their own right. They are radical acts of retrieval and survival in and of themselves. However, despite these notable examples, twentieth-century anarchism did not build upon Kropotkin's interest in the Middle Ages, nor upon the value he accorded history more generally. Although the historiography of Kropotkin and Rocker seems simplistic, even naive today (something I will say more about in due course), their instinct that history mattered has largely disappeared from academic anarchism, and academic history writing has developed without any appreciable input of anarchistic ideas. More recently, several anarchist writers, notably Peter Gelderloos and David Graeber, have re-engaged with academic research on the pre-modern human past, though with a slight tendency to cherry-pick examples to fit a preconceived story. ${ }^{3}$ The slenderness of academic anarchist engagement with history is something which has recently been noted by other authors. In the intellectual history of anarchism itself, several recent works have demonstrated 
If you wish to cite this pre-publication paper, please use the following format: lan Forrest, 'Medieval History and Anarchist Studies', forthcoming in Anarchist Studies, 29:1 (Spring 2021).

how putting canonical anarchist authors in a broader context could benefit the study of the modern movement's history. In 2013 Matthew Adams drew attention to the suffocating effect that the 'purity' of the anarchist canon has had on writing anarchist intellectual history; in the same year Sho Konishi's major book on Russo-Japanese intellectual connections and 'cooperatist anarchism' in the late-nineteenth and earlytwentieth centuries demonstrated the fruitfulness of the broadening that Adams advocated; and in 2016 Ruth Kinna's critical biography of Kropotkin provided a further example of the contextual approach that promises to pull the history of anarchism out of its self-referential cul-de-sac. ${ }^{4}$ The key feature of these works is that they place anarchist ideas in a broad intellectual context instead of presenting isolated portraits of famous individual writers and activists.

However, despite this heritage it is notable that there is today very little anarchist history as opposed to histories of anarchism. As a result of its marginalisation from academic history writing, anarchism has not been developed as a mode of historical enquiry in the way that feminist history involves much more than the history of feminism, or that Marxist history encompasses more than just the history of Marxism. And these two comparisons are not idly chosen: anarchists may learn much from the richness of feminist and Marxist historiography and to the ways in which, at various times, they have fed back into the identity of those movements and their sense of political purpose..$^{5}$ Much scholarship in both traditions has also taken place outside the formal academy, a practice and principle in which anarchists are particularly invested. Feminism especially has articulated new questions and new chronologies, proposed History and Anarchist Studies', forthcoming in Anarchist Studies, 29:1 (Spring 2021). 
If you wish to cite this pre-publication paper, please use the following format: lan Forrest, 'Medieval History and Anarchist Studies', forthcoming in Anarchist Studies, 29:1 (Spring 2021).

new sources and objects of study, and changed the curricula in many university history departments. All this has been achieved because understanding the past has been seen as crucial to changing the future: as Judith Bennett observes, 'the power of patriarchy in our lives today partly rests ... on our failure to understand how it has worked in past times'. ${ }^{6}$ In addition to this, feminist historians have realised that questions generated by present oppression and inequality can lead historians to a better - that is a fuller and more critical - understanding of the past.

Translating the terms of a debate about feminism into one relevant to anarchism involves no great conceptual leap, and it is easy to see how Bennett's comment could apply to an anarchist historiography. We might say that forms of domination which inhibit autonomy and cooperation cannot be properly recognised, understood and challenged without a critical awareness of the situations in which domination has occurred in the past, and why its nature has varied so much across time and space.

But first we need more anarchist historians, and they are in short supply. David Graeber's 2009 assessment that there are 'thousands of Marxist academics but very few Anarchist ones' seriously underplays the presence of scholars with anarchist sympathies in political science, anthropology and archaeology, but it is certainly true of history. Graeber has proposed that this state of affairs exists 'not because anarchism is anti-intellectual so much as because it does not see itself as fundamentally a project of analysis. It is more a moral project."7 Anarchism has not, he claims, often been thought of as an interpretative or analytical perspective. Again, while this is debateable in 
If you wish to cite this pre-publication paper, please use the following format: lan Forrest, 'Medieval History and Anarchist Studies', forthcoming in Anarchist Studies, 29:1 (Spring 2021).

relation to the social sciences generally, it is pretty true of history. Archaeologists, historians' fellow students of the human past, have begun to demonstrate just what is possible, and recent developments in my own field of medieval history suggest that a new anarchist historical consciousness may be emerging. One important scholarly threshold was recently reached with a special issue of the Society for American Archaeology's Archaeological Record devoted to anarchy and archaeology in 2017, and perhaps a second with the foundation of an Anarchist Approaches to the Middle Ages network at the International Medieval Congress in 2019. It is telling, however, that even as they bring together anarchist scholars and scholars interested in anarchism, the editors of the Archaeological Record felt obliged to draw attention to the fact that anarchism has 'long been disregarded by academics'. ${ }^{8}$ Despite growing interest in putting anarchist ideas to work in neighbouring disciplines, however, the lack of an explicitly articulated anarchist mode of historical enquiry leaves both history and anarchism intellectually poorer than they need be.

This paper makes the case for medieval historians to adopt an anarchistic approach to their subject, and for anarchists to read more medieval history.

How could medieval historians benefit from adopting an anarchist perspective?

What would an anarchist perspective or method for medieval historians, and perhaps historians in general, look like? I ought to say at the outset that I am not here proposing an anarchist theory of historical development, after the manner of Alan Carter's anarchist version of Gerry Cohen's application of analytical philosophy to Marxist 
If you wish to cite this pre-publication paper, please use the following format: lan Forrest, 'Medieval History and Anarchist Studies', forthcoming in Anarchist Studies, 29:1 (Spring 2021).

historical dialectics. ${ }^{9}$ Mine is a more practical agenda for getting on with doing some history in an anarchist way. There are so many fruitful and imaginative currents in anarchist thought and practice, whether in academia, activism, or the arts, where engagement with historical research and writing is possible, that everything I say here ought to be taken as personal and provisional: in the first instance I am writing this as a reflection upon my own work as a historian. But I will begin by mentioning three encouraging examples that historians could learn from: two anthropologists already read by medievalists - James Scott and David Graeber - and the emerging movement of anarchist archaeologists, including the Black Trowel Collective. Together they provide instructive starting points for thinking about an anarchist history that is more than just the history of anarchism.

Scott's 2009 book The Art of Not Being Governed was subtitled 'an anarchist history of Southeast Asia' and looked at state-resisting mountain and forest societies in the modern era. He was much influenced by Pierre Clastres's classic study of Amazonian forest dwellers, Society against the State, and by the geographer Willem van Schendel's coinage of the name 'Zomia' to designate a transnational upland region spreading across the borders of modern Cambodia, Laos, Vietnam, Burma, and China. ${ }^{10}$ Scott's Zomia is inhabited by peoples who, so he argues, fled lowland state-building projects and adopted economic, social, and cultural practices to keep states at bay and to suppress power inequalities. As a piece of anarchist historiography it is notably exceptional in taking an anarchist approach not just to supposedly-stateless people, but also to the histories of the states that stimulated their emergence, both themes that I will turn to in 
If you wish to cite this pre-publication paper, please use the following format: lan Forrest, 'Medieval History and Anarchist Studies', forthcoming in Anarchist Studies, 29:1 (Spring 2021).

more detail shortly. The Art of Not Being Governed has generated a great deal of discussion and criticism in Southeast Asian area studies, with one commentator conspicuously calling for a reinvigoration of Scott's 'venerable anarchist perspective', an approach 'which has almost disappeared from academic writing'.11

Although Scott's main interests lie in the twentieth century, his is a very historical anthropology, and his analysis stretches back into the nineteenth century, besides making allusions to earlier periods. This constitutes an invitation to comparison and makes his work very attractive, but it does not quite have the 'time depth' that would put him immediately into dialogue with historians of the pre-modern past. However, his earlier ideas about 'hidden transcripts' and 'weapons of the weak' have already had a strong influence upon medieval history research. ${ }^{12}$ There is therefore a familiarity with his work that might encourage medievalists to begin to think of themselves as anarchist scholars. Moreover, as I will suggest in due course, the concept of 'Zomia' (or perhaps the artfully open-ended 'zomias') is full of potential for medievalists to work with because during the period c.500 to c.1500CE ungoverned spaces were at least as common as governed ones, and yet they have received far less attention from historians. ${ }^{13}$

Besides his wider popular and scholarly reach, Graeber is another anarchist anthropologist who is read and discussed by medievalists in particular, especially his 2011 book on the history of debt, which covered some aspects of medieval economic and cultural life in a whistle-stop tour of world history, and was recently the focus of a 
If you wish to cite this pre-publication paper, please use the following format: lan Forrest, 'Medieval History and Anarchist Studies', forthcoming in Anarchist Studies, 29:1 (Spring 2021).

conference organised by medieval historians. ${ }^{14}$ Graeber's willingness to read in medieval history (as well as a host of other fields) is a hallmark of his eclectic approach, proving that recent research on the distant past can be of use to anarchists. However, Graeber tends to fit the examples to his big idea (rather in the manner of that other great history-hungry social thinker Charles Tilly), and I think it is fair to say that he intends his synthetic approach principally to be a provocation to further research by historians, much as his 2004 pamphlet Fragments of an Anarchist Anthropology was for the discipline in which he was trained. ${ }^{15}$ Medieval historians of credit and debt might question some of Graeber's conclusions, particularly about the supposed power of debt to drive out other - more reciprocal and egalitarian - moralities, but they ought to welcome the radicalism of injecting the moral meaning of all debt (not just usury) into the historical debate. It is a radical opening-up of the subject that could only come from an anarchist perspective: 'what is a debt, anyway?'16

Alongside anthropology, archaeologists have also come to be attracted to anarchistic ways of thinking. In 2016 the Black Trowel Collective launched a manifesto for anarchist archaeology, as 'an alternate way to think about the past and to consider our methods and practices in the present'. ${ }^{17}$ As a perspective from which to think about and study the past, it has much to offer anyone interested in a radically-humane way of thinking about history. The manifesto recommends an archaeology that does not take for granted that organisational complexity derives solely from 'elite control', which searches for evidence of resistance as well as for the exercise of power, and which asks critical questions about scale and agency in human life. It also makes proposals for how History and Anarchist Studies', forthcoming in Anarchist Studies, 29:1 (Spring 2021). 
If you wish to cite this pre-publication paper, please use the following format: lan Forrest, 'Medieval History and Anarchist Studies', forthcoming in Anarchist Studies, 29:1 (Spring 2021).

archaeology ought to be conducted, as a non-hierarchical and inclusive way of studying the human and non-human world. Although not exactly mainstream, yet, there is a good deal of support for anarchist approaches within the archaeology community, and the potential for more. Perhaps this is because when archaeologists move from thinking about objects to thinking about people, they more often situate themselves side-by-side with those people, in contrast to historians, who can tend to look down upon their 'subjects' from the lofty archives of state power. ${ }^{18}$ This tendency has encouraged some archaeologists to think with concepts culled from anarchist theory. For instance James Flexner, writing about Pacific island archaeology, and Matthew Sanger, writing about the evidential potential lying in traditional ethnographic studies, both make creative use of the idea of 'counterpower', the mechanisms by which hierarchy is suppressed and dis-incentivised in non-hierarchical societies. ${ }^{19}$ Although he uses a different vocabulary, this is also what Scott's anthropology of Southeast Asia has sought to elucidate. These are projects of analysis that draw upon a variety of intellectual precedents, and are responsive to the vagaries of place, evidence and method, but which are - crucially made possible by taking an anarchist's view of the world.

Taking inspiration from the anthropologists and archaeologists, as well as from the much deeper tradition of writing against domination in feminist historiography, I shall now present three examples of fields in which medieval history could be reinvigorated by the adoption of an anarchist perspective. They are the history of 'non-state' spaces or zomias, the history of domination and inequality, and the history of states and institutions themselves. These are merely the things that currently interest me, and I 
If you wish to cite this pre-publication paper, please use the following format: lan Forrest, 'Medieval History and Anarchist Studies', forthcoming in Anarchist Studies, 29:1 (Spring 2021).

make no claims whatsoever to these being the 'right', 'best' or only topics that would benefit from an anarchistic approach. There is also huge potential for anarchist modes of historical enquiry in all aspects of cultural history, and - perhaps most fruitfully and immediately - in environmental history, a field where the concepts of the Anthropocene and Capitalocene are encouraging a radical reorientation of how the human past is conceived and interrogated, for instance in the work of the archaeologist Theresa Kintz and the historian Amanda Power. ${ }^{20}$

\section{Non-state spaces}

The study of non-state spaces on the model of Scott's Zomia is beginning to thrive amongst archaeologists, such as those mentioned above, and with a few pre-modern historians as well. In particular Peter Thonemann has shown how useful Scott's model of an anarchist society can be for re-interpreting regions long (mis)understood in terms of failure or collapse. Thonemann presents a detailed case for re-thinking the history of ancient Phrygia (inner Anatolia between c.500 and c.100BCE), where a formerly urban and literate state morphed into a 'post-literate, post-urban, highly fragmented, cellular agro-pastoral society'. ${ }^{21}$ By assuming that the ancient Phrygians were rational people striving to maintain a tolerable way of life, instead of foolish and ignorant folk rejecting the proper Roman way of doing things, Thonemann is able to restore to them some meaningful historical agency and significance. He finds the conscious rejection of hierarchy and centralised power a better fit for the Phrygian evidence than a model of failure and decline. 
If you wish to cite this pre-publication paper, please use the following format: lan Forrest, 'Medieval History and Anarchist Studies', forthcoming in Anarchist Studies, 29:1 (Spring 2021).

Bearing this example in mind it is perhaps with the histories of such regions, both those beyond the reach of states, and those where coercive hierarchies appear to have been rejected in favour of another way of life, that an anarchist approach might make the most immediate headway. Doing so would involve relegating the importance of centralised power in the definition of historians' questions, and allowing the possibility that people would choose not to live under the 'protection' of a state, preferring a more autonomous and egalitarian existence, whatever its concomitant dangers. ${ }^{22}$ Moreover, if we were to broaden the theoretical conversation beyond Scott's Zomia thesis to incorporate other elements of anarchist thinking, historians would find such commonplaces of anarchist thinking as heterarchy, acephalous networks, confederation, counterpower and consensus decision-making to be useful tools with which to think about the history of ungoverned spaces. ${ }^{23}$ I would not advocate for historians to accept such ideas uncritically (for which see the final section of this paper), but to use them to challenge received orthodoxies and generate new questions that can then be addressed to existing and new bodies of evidence.

Writing the history of places where states and hierarchies are absent or minimal nevertheless runs up against problems of both evidence and interpretation. Beyond the reach of centralised power, people's lives are less likely to leave documentary traces, and so we must use the state's records against the state's purposes. This is something that medieval historians are already adept in, having used government and legal records to study all kinds of subversion, 'deviance', and minority ways of life, but the challenge grows the further one gets from the core territories of medieval polities. ${ }^{24}$ 
If you wish to cite this pre-publication paper, please use the following format: lan Forrest, 'Medieval History and Anarchist Studies', forthcoming in Anarchist Studies, 29:1 (Spring 2021).

There is some potential for using the private archives of medieval traders as evidence for the character of ungoverned regions, and more might be made of travel and historical writing, notably in the Islamic tradition of Ibn Fadlan and Ibn Khaldun, but written records have their limits. ${ }^{25}$ Traders' and travellers' accounts of ungoverned spaces notably portray an imagined 'other' against which a vision of their own civilisation is constructed. ${ }^{26}$

Using the archaeological evidence, with which historians of non-state spaces must become more familiar if we are to leave institutional archives behind, can nevertheless also be problematic. For instance, one of Thonemann's pieces of evidence for the retreat of state power in ancient Phrygia is the disappearance of monumental architecture from the region in the aftermath of the Persian invasion. ${ }^{27}$ In the case he describes this works persuasively, where the retreat of the state was connected with deurbanisation, but elsewhere the absence of monumental structures occurs in thriving urban cultures, conspicuously in West Africa between c.800BCE and c.1400CE. The physical evidence here - in the spatial patterning of structures and settlements and the absence of major public buildings - has been interpreted by Roderick McIntosh as a 'self-organising' and heterarchical landscape. ${ }^{28}$ Just how useful the Zomia thesis could prove in cases of putatively non-hierarchical urbanism remains to be seen. In order to pose questions rather than leap to conclusions, we should also acknowledge other configurations of social organisation and architecture: at one end of the spectrum we have the stateless culture that produced the impressive stone brochs of Western Scotland, the Hebrides, and the Northern Isles between c.150BCE and c.150CE, and at History and Anarchist Studies', forthcoming in Anarchist Studies, 29:1 (Spring 2021). 
If you wish to cite this pre-publication paper, please use the following format: lan Forrest, 'Medieval History and Anarchist Studies', forthcoming in Anarchist Studies, 29:1 (Spring 2021).

the other we have the nomadic empires of the Eurasian steppes and the North American plains which relied largely upon tents, which leave far less of an archaeological trace than permanent dwellings. ${ }^{29}$

In addition to problems of evidence the Zomia thesis also raises questions of interpretation, and these are of two kinds. First, claims for the existence of egalitarian social relations and state flight can always be challenged on empirical grounds: scholars may suggest alternative evidence and alternative interpretations of the evidence.

Second, even if historians agree on the existence of an egalitarian society, does it follow that this came about intentionally, as a result of conscious efforts to resist the emergence of hierarchy and the encroachment of governing power?

However, while acknowledging this methodological challenge a sense of perspective ought to be maintained, bearing in mind that the study of top-down state power is saturated with precisely the same kind of normative functionalism: order coming about supposedly because rulers intended it. Medieval historians might also strive to form new interpretations of familiar evidence, such as the frequent community denunciations of neighbours to the church courts for working on Sundays which are usually seen as evidence that medieval peasants had internalised ecclesiastical time. Since these denunciations are sometimes accompanied by tart remarks about material gain and personal enrichment we might in fact interpret them as one means of preventing the emergence of damaging wealth hierarchies. ${ }^{30}$ Inequality may have been managed in this way because, as the sociologist Richard Sosis has suggested, religious behaviours 
If you wish to cite this pre-publication paper, please use the following format: lan Forrest, 'Medieval History and Anarchist Studies', forthcoming in Anarchist Studies, 29:1 (Spring 2021).

are 'cheaper to monitor than other activities' taking place in bounded spaces at particular times. ${ }^{31}$

A degree of prior familiarity, or at least family resemblance, might well dispose medievalists to work with Scott's Zomia thesis. In many ways it builds upon Fernand Braudel's famous characterisation of feudal authority as having 'failed to catch in its toils most of the mountain regions', an idea which has already stimulated a good deal of research. ${ }^{32}$ While Braudel and Scott focussed on mountains, historians would no doubt find it interesting to explore the existence and character of ungoverned spaces in island, desert, steppe, and marshland areas, or even in small pockets in more intensively settled and governed landscapes. ${ }^{33}$ However, it would be important not to erect toodeterminist a model connecting particular terrain to certain forms of social organisation. A historical comparative approach to zomias would have to accommodate and explain forests and marshes where states could operate, and perhaps even arable lowlands where they could not. An open mind and a flexible model would be essential. This potential variety would indeed be better served by the geographers' concept of 'socioecological regimes', in which humans (and potentially their history) are seen as part of an eco-system, rather than simply responding to it. ${ }^{34}$ Indeed this terminology and integrated approach has been pioneered by the medieval economic historian Bruce Campbell. 35

\section{Domination and inequality}


If you wish to cite this pre-publication paper, please use the following format: lan Forrest, 'Medieval History and Anarchist Studies', forthcoming in Anarchist Studies, 29:1 (Spring 2021).

In addition to the history of non-state spaces, anarchism also offers a great deal to historians of inequality in the Middle Ages. The study of medieval European non-elites has for the most part been conducted by social and economic historians, and while this has produced some amazing insights into local ways of life and thought, including the widespread practices of reciprocity, the workings of power and subordination have not received as much detailed attention as they deserve. Partly this is a result of the excessive specialisation that means social/economic and political historians regard themselves as doing two completely different things, but it is also - I contend conditioned by medievalists' collective failure to ask questions about some of the most important features of life in the period, namely class and, to a lesser extent, gender inequalities, subordination, and domination. Despite a great deal of research into the structure of peasant societies, medieval historians have tended to see them just so - as structuring frameworks - taking them for granted and not subjecting their genesis and development to analysis as systematically as they deserve to be.

We medievalists need to shift our sense of significance, taking inspiration from other movements to change the object of history. The anarchist tradition provides fresh and invigorating ways of thinking about significance in history because of its political and moral standpoint. Anarchist politics of revolutionary change present historians with a useful perspective on political significance: in contrast to Marxism's deferral of meaningful social change to a future time, following violent revolution in which collateral victims are expendable in the name of historical destiny, many anarchists see revolution in the politics of immediate personal and social transformation, redrawing 
If you wish to cite this pre-publication paper, please use the following format: lan Forrest, 'Medieval History and Anarchist Studies', forthcoming in Anarchist Studies, 29:1 (Spring 2021).

the patterns of social interaction now rather than in the future. This 'prefigurative politics' derives from and encourages participatory and non-hierarchical values, a strong sense of equality, and the convergence of feminist, anti-racist, and LGBTQ+ resistance in the current 'post-anarchist' movement. The thing that binds this loose confederation of activists and thinkers together is the identification of multiple and interlocking forms of domination. ${ }^{36}$ Echoing and critiquing liberal theories of 'intersectionality', anarchists seek to make links between forms of domination that are often - in liberal society and history writing - deemed to operate discretely and are dealt with in ways that prevent the emergence of true radicalism (in the sense of getting to the root of things, either in social policy or history writing). ${ }^{37}$ In resisting this separation of the interests of the oppressed, anarchism opens up a space in which both the systems and the personal experiences of domination and inequality can be studied holistically and a critical assessment made of the role of the state in fomenting discrimination and inequality, something not seen in liberal intersectionality. In this context, historical significance could be said to be the inalienable possession of every person, not the preserve of the most visible presence or the loudest voice in the room/archive.

However, because there is not as yet a very well-developed anarchist approach to history, we must turn to other movements more invested in historical analysis, to see what this could mean. As I have suggested, primary among these is feminism. As Gerda Lerner wrote in 1979 'only a history based on the recognition that women have always been essential to the making of history and that men and women are the measure of 
If you wish to cite this pre-publication paper, please use the following format: lan Forrest, 'Medieval History and Anarchist Studies', forthcoming in Anarchist Studies, 29:1 (Spring 2021).

significance, will there be a truly universal history.' 38 This focus on challenging the 'measure of significance' from a radical standpoint is something that feminism has shared with anarchism in principle, although there is an extensive feminist historiography that realises the desire and very little anarchist literature that could boast a similar achievement. ${ }^{39}$ Nevertheless, it would be fruitful to establish an anarchist approach to history based on the achievements of feminism and ask the radical question: who or what is the measure of significance in historical enquiry?

It is possible that a confluence of feminist and (putative) anarchist approaches to medieval history could create more links between the rather atomised sub-fields in which social historians operate, magnify the historical attention given to subordinated people, and together have a greater impact on mainstream history writing. Although it is true that feminists have explored the changing bases of patriarchy in many detailed ways, and there are numerous studies focussed on revealing and explaining the experiences of abused children, prostitutes, and beggars amongst other very marginal groups, two things have blunted the impact of this humane and anarchist-friendly field of study. ${ }^{40}$ First, medieval women's history as a whole tends to revert to the betterdocumented women of the upper peasantry, middling townspeople, and noble elites. There is too much complacency about which women constitute the measure of significance. Second, for the majority of social and economic historians who study mainly men, women's history is a separate and optional add-on, and the measure of significance often remains stubbornly masculine.

If you wish to cite this pre-publication paper, please use the following format: lan Forrest, 'Medieval History and Anarchist Studies', forthcoming in Anarchist Studies, 29:1 (Spring 2021). 
If you wish to cite this pre-publication paper, please use the following format: lan Forrest, 'Medieval History and Anarchist Studies', forthcoming in Anarchist Studies, 29:1 (Spring 2021).

An anarchist approach to medieval domination and inequality offers the prospect of recalibrating the measure of significance on a wide scale. Again taking a cue from feminism, anarchist medievalists would do well to tread a humane and informed line between recognising the multiplicity of values by which women and men have lived in past societies, and taking for granted that certain conditions - like poverty, slavery, subordinated agency, sexual abuse, violence and so on - are a priori undesirable states of being that are in need of historical explanation. No matter that in the Middle Ages certain powerful discourses of subordination and domination were widely seen as natural, even by some of their victims; historians ought to be seeking to understand and explain the experiences of the dominated, even if this means situating ourselves in a place where the archive is silent. If we truly want to equalise the 'measure of significance' we must tackle subjects that our archives hide more often than record. Adopting such a critical anarchist perspective is necessary in order to prevent ourselves ever being too-easily satisfied that we have successfully understood the causes and social meaning of domination.

What might this look like in practice? Take for example the historiography of rebellion and revolt, which has thriven on historians' identification with the rebel, holding out the prospect of a history in which the measure of significance is broad indeed. Major historians (all notably male), such as Rodney Hilton on the English peasants' revolt of 1381, Eric Hobsbawm on the 'social bandits' of nineteenth and twentieth century Italy, Boris Porchnev on seventeenth century French revolts, and Edward Thompson on working-class agitation in industrial England, all wrote as Marxists, putting onto the 
If you wish to cite this pre-publication paper, please use the following format: lan Forrest, 'Medieval History and Anarchist Studies', forthcoming in Anarchist Studies, 29:1 (Spring 2021).

historical stage actors with whom they identified to one degree or another. ${ }^{41}$ And yet there were significant limits to their visions of history. Revolts were often led by local elites and their discipline maintained by violence. The peasants' revolt of 1381 is a case in point: the rebel leaders have now been shown to have been village worthies and small-time employers on the make. ${ }^{42}$ This knowledge has not, however, translated into any historical work on the violence and domination within the rebellion, leaving Hilton's 'history from below' privileging the agency of people who were - frankly speaking - the patriarchal elites of their own small patriae. What of the servants, the young unmarried men and women, the landless poor, the infirm and so on, whose participation in rebellion has been overshadowed by better-documented rebels? It must be said that while historians of rebellions have done great things with difficult sources, their sense of what is significant has too often reverted to a norm of able-bodied masculinity and locally-held power. For readers not immersed in medieval social and economic history, it is worth noting at this point that although the sources by which we can know about such marginalised people are frustratingly taciturn, they do exist (among judicial records and archaeological data in particular): historians cannot blame their sources for their own failure to ask certain questions.

While the anarchist movement has had its own problems with male dominance (as well as whiteness), ${ }^{43}$ the focus on multiple forms of domination is a useful reminder to historians that power is never singular or unidirectional, in any historical context and whoever is cast as the historical agent. In addition historians of revolts could benefit a great deal from anarchists' theorisation and practice of their own, modern, political 
If you wish to cite this pre-publication paper, please use the following format: lan Forrest, 'Medieval History and Anarchist Studies', forthcoming in Anarchist Studies, 29:1 (Spring 2021).

struggles, in which the desirability of diverse aims and diverse means is prevalent. ${ }^{44}$ Medieval European rebellions - at least the better-documented ones - reveal a world of popular politics in which a plethora of radical and sometimes contradictory ideas swirled around the mass mobilisation of protesters. In England in 1381 for example, resistance to taxation, calls for the end of all lordship (except that of the king) and all church power (except that of the archbishop of Canterbury), the abolition of serfdom, heretical murmurings, and the execution of lawyers and government officials, emerged alongside xenophobic massacres, appeals to religious conformity, extreme violence against those who resisted rebel requisitioning, and rear-guard action by peasant elites who objected to aspects of government power but very much wanted to protect their own petty authority. ${ }^{45}$ Anarchist approaches to organisation without leadership could also pose provocative questions to historians interested in the growth and spread of pre-modern social movements.

\section{State/institutions}

While it is somewhat obvious how an anarchist perspective could be valuable to historians of non-state spaces and of domination or rebellions, it is perhaps less clear what it would have to offer the history of the state and institutions in the medieval period. However, I believe that an anarchist approach is essential to understanding this subject. In my own research into the social history of political and religious institutions, primarily in late medieval England, I find it necessary to actively resist the persistent assumption of many historians that the growth of centralised states and institutions is a 
If you wish to cite this pre-publication paper, please use the following format: lan Forrest, 'Medieval History and Anarchist Studies', forthcoming in Anarchist Studies, 29:1 (Spring 2021).

positive phenomenon, and anarchism helps with this. I do not mean to say that historians make overt statements in support of the role of state power, or even perhaps - consciously admit as much to themselves, but a tacit belief in the rightness and naturalness of states is an almost indelible element in much history writing. It is an assumption that has to be recognised and named before it can be unravelled and resisted, an idea arising from the long historiographical tradition that took the elaboration of state power ('constitutional history') to be the proper business of historians.

Despite many challenges and revisions to constitutional history, historians of politics are still working under its shadow. It is a manner of writing about the state that is highly teleological and blinkered: state growth is treated as a 'good' not warranting critical examination because in most liberal historiography and social science writing modern states are considered as - on balance - good, or better than the alternatives, whatever wrongs they may do. This has been challenged by many anarchist writers, including Rocker, who wrote that the person 'who believes that he cannot exist without the organized force which is personified in the state must be ready to accept all the consequences of this superstitious belief', sentiments recently echoed by the philosopher Jan Philip Reemtsma pointing out that a 'persistent trust in modernity' continues 'despite our knowledge that it is other than we presumed it to be' with its systematic violence and reliance upon domination. ${ }^{46}$ Teleologies of the state are rarely investigations into the capacity for surveillance, normalisation or genocide, though 
If you wish to cite this pre-publication paper, please use the following format: lan Forrest, 'Medieval History and Anarchist Studies', forthcoming in Anarchist Studies, 29:1 (Spring 2021).

histories of heresy and Jews in medieval Europe have shown an interest in these themes. ${ }^{47}$

Historians of institutions and the state are particularly adept in this sort of selfdeception or uncritical omission. We often allow our attention to be caught by the deeds and records of the powerful to the exclusion of other perspectives. As Scott has written, the 'condensation of history, our desire for clean narratives, and the need for elites and organisations to project an image of control and purpose all conspire to convey a false image of historical causation'. ${ }^{48}$ We see this in the language used to describe change in the history of state power: the verbs 'to grow' and 'to decline' set the pattern of positive/negative binaries in untold numbers of academic and popular history books, while abstract nouns such as 'consolidation' and 'fragmentation', and adjectives like 'strong' and 'weak' add to the normative discourse in which political history is habitually written. It takes an anarchistic view of the world resist the weight of that accumulated tradition.

The key anarchist insight on the nature of the state comprises a value judgement and a programme for analysis. The value judgement is that government is a negative force in human society, and that the growth of states has closed off other trajectories with potentially more desirable outcomes. The programme for analysis arises from anarchists' openness and attention to other forms of social and political organisation, from the heterarchies studied by archaeologists, to the syndicalism of the nineteenth and twentieth centuries. Anarchists know that order and indeed governance can exist 
If you wish to cite this pre-publication paper, please use the following format: lan Forrest, 'Medieval History and Anarchist Studies', forthcoming in Anarchist Studies, 29:1 (Spring 2021).

without government, and they are keenly attuned to the depredations of governing power upon individuals, classes and communities.

If medieval historians were to steal themselves to resist the accumulated traditions of constitutional history, more consciously and from an anarchist perspective, they would be more likely to open up a fuller range of past experiences to historical study, principally the experiences of those people who suffered as a result of state and institution formation. In saying this I am advocating a more radical shift of assumptions than that which has been achieved by Marxist and liberal-democratic revisions of the constitutional master narrative. In most traditional political and institutional history non-elites are the people to whom things are done; they are the passive world which the powerful mould and rule. One reaction against this took the form of Marxist historians' - such as those mentioned above - interest in extraordinary revolutionary moments when 'the people' seemed to walk onto the stage of history (only to leave it promptly in many instances), while another came from liberal-democratic historians who have written ordinary people into the history of state-building 'from below'. In contrast to Marxists writing on revolutions, historians such as Peter Blickle and James Masschaele have seen 'the people' as a more permanent presence in political (as opposed to economic and social) history, fulfilling minor state functions relating to taxation, law and social regulation. ${ }^{49}$ Theirs was a welcome development, but insufficient to trouble the place of state-building and power-seeking as the unquestioned and proper business of historians. The role of ordinary people in state building - and by implication in the 
If you wish to cite this pre-publication paper, please use the following format: lan Forrest, 'Medieval History and Anarchist Studies', forthcoming in Anarchist Studies, 29:1 (Spring 2021).

state itself - was celebrated as a great human achievement. The people were historically significant when they contributed to the growth of states.

Such an attitude leaves no room for historical investigation of the effects of state growth, either upon those members of the lower orders who contributed to it, or those who suffered its direct and indirect impact. An anarchist perspective in which the negative effects of government are stressed is enormously helpful as a reminder to ask more critical questions. This may include a re-evaluation of the historical role played by some of the people who actually contributed to state and institution formation. For example, noting the potential and limitations of the 'state-building from below' approach, I have recently written about the role played by peasant elites in the formation of the institutional church in the Middle Ages: they were needed by the church and they accrued social capital by being its local brokers, forming a symbiotic relationship with power. But alongside these group benefits, individual members of that peasant elite found that their lives were more regulated than ever before, their sexual behaviour monitored and judged, and deviant ideas labelled as heretical. Furthermore, the identification of a tiny village elite as 'trustworthy' informants and enforcers relied upon and exacerbated the myriad inequalities of the thirteenth to fifteenth centuries, notably keeping women out of the developing public sphere..$^{50}$ Building institutions demonstrably meant promoting inequalities.

We need more feminist and anarchist histories of power and institutions. An anarchist perspective that rejects the whole idea that the concentration of political power is 
If you wish to cite this pre-publication paper, please use the following format: lan Forrest, 'Medieval History and Anarchist Studies', forthcoming in Anarchist Studies, 29:1 (Spring 2021).

inherently desirable, offers such a radical alternative to the mostly-unarticulated assumptions of political history, that historians who adopt it might more easily question both what it is they are studying, and why. As the archaeologist Stuart Rathbone recently argued, 'the inverted values of anarchism force a radical reassessment of many basic assumptions about human society'. ${ }^{51}$ For all students of the human past, identifying the thing we seek to explain is - unavoidably - a political and a moral choice. Our privileging of certain topics and questions over others has political consequences even if it arises from nothing more than an unexamined assumption about the proper object of historical enquiry. Anarchism tears down the tacit value judgements that favour state power as the object of history, and invites us to think again about our measures of significance. For example, medieval historians could take note of anarchist archaeologies and developments in the science of complexity, in which the existence of horizontal egalitarian relations is seen as a natural or successful human endeavour, while their replacement by hierarchies of power is regarded as social failure and a reversion to simple forms of domination. ${ }^{52}$ This is an inversion of the value-judgements restraining the traditional narratives of political history, and an exciting basis from which to formulate new questions.

What if the study of medieval governing institutions was predicated upon a radical refashioning of the thing to be explained? What if the means by which populations were dominated, and the effects of domination upon them, were the salient questions? We would not frame our analysis of Edward I of England around how he built a judicial state, raised taxes, and made war on Scotland (although these traditional questions 
If you wish to cite this pre-publication paper, please use the following format: lan Forrest, 'Medieval History and Anarchist Studies', forthcoming in Anarchist Studies, 29:1 (Spring 2021).

would still be answered, albeit in a more interesting way), but how the experiences of people using the courts, paying taxes, and finding themselves caught up in warfare changed during his reign, besides explaining the ability of some regions to resist one or more components of his state building. We would do so because these are the most significant questions about his strengthening of royal power, and because not placing them at the centre of our analysis means failing to ask the right questions about those mechanisms of power. An anarchist perspective would see the loss of community autonomy concomitant to the rise in governing power in the later thirteenth century as much more significant than the achievements of 'strengthening' government. ${ }^{53}$ As James Flexner writes of the study of the past, 'it is probably about time to start to experiment with frameworks other than the orthodox model'. ${ }^{4}$

\section{How could anarchists benefit from reading more medieval history?}

The ways in which anarchists could benefit from reading more (medieval) history are reflections of the things that medievalists could gain by thinking with anarchism more often. Traffic between two fields of study should always be two-way, and while medieval historians could learn a great deal from anarchist theory and approaches, they also have much to offer that would enrich anarchist studies. The headline contribution ought to be fairly clear by now: anarchism has the potential to be a much more powerful analytical project than it is currently, and an anarchist approach to history could be a major element of that. History is one of the major ways in which human potential is imagined, and a core element of much formal and informal education, and yet anarchist 
If you wish to cite this pre-publication paper, please use the following format: lan Forrest, 'Medieval History and Anarchist Studies', forthcoming in Anarchist Studies, 29:1 (Spring 2021).

history is currently largely confined to the history of anarchism. This imposes unnecessarily strict limitations upon the influence of anarchism: if it is to shape the way the world is seen - and thereby the way that alternative futures can be imagined anarchism ought to engage more with the manner in which history is written. A mushrooming of anarchist approaches to history would lead to new theoretical insights and produce forms of knowledge about the course of history in which anarchist principles would play a crucial role.

Were anarchists to begin reading more medieval history in particular, they would find the door ajar, if not yet fully open, to their interests and attitudes. Without being anarchists, many medieval historians already adopt positions of hostility or scepticism towards power as the basis for their analyses. For example, in his book on the 'origins of European government' in the twelfth century, the respected Harvard historian Tom Bisson conjures an image of rulers who 'feasted on the violence their peoples suffered' at the hands of feudal lords, justifying as it did the extension of governing power. ${ }^{55}$ Even though I'm fairly certain Bisson would not describe himself as an anarchist, his approach to power is symptomatic of a tendency that suggests the potential for dialogue between medievalists and anarchists. We already speak some of the same language. Much of this shared discourse derives from various forms of radical history - feminism, postcolonialism, deep history and so on - which have grown in popularity as academic historians have become less comfortable with the all-too-recent identity of the discipline as the training ground for civil servants and imperial administrators. Such 
If you wish to cite this pre-publication paper, please use the following format: lan Forrest, 'Medieval History and Anarchist Studies', forthcoming in Anarchist Studies, 29:1 (Spring 2021).

shifts have seen medieval historians adopt perspectives much more in tune with anarchists' concerns.

Besides the recent blossoming of forms of history that would be of great interest to anarchist readers, medieval historians are, by training and long experience, well aware that world history has presented many alternatives to the depressing and inhibiting narratives of modernisation. Moreover, some are increasingly positioning themselves as the bearers of an explicit critique of modernity, providing the empirical basis for a rejection of the 'no alternative' mantra of globalisation and neo-liberalism. ${ }^{56}$ This is becoming - or has the potential to become - part and parcel of a critical medieval global history which attacks the celebration of transnational integration on the basis of capital accumulation and exploitation: the default ethical position of much writing in modern global history. Because medievalists often occupy an outsider position, both within the historical profession and in relation to the paradigm of 'modernity', they tend to be more sceptical and critical about the myopic presentism of globalisation. ${ }^{57}$ This movement is in its infancy, and so the potential for productive dialogue is great, with anarchist ideas, alongside those of indigenous movements and postcolonial politics, offering new means to study how and when people have and have not been drawn into dominating political structures and unequal social relationships.

Because the sorts of societies that medievalists study typically exhibit weak but ambitious state power alongside wildly varying levels of local autonomy and resistance to hierarchy, they could furnish materials that would be useful for bridging the 
If you wish to cite this pre-publication paper, please use the following format: lan Forrest, 'Medieval History and Anarchist Studies', forthcoming in Anarchist Studies, 29:1 (Spring 2021).

epistemological gap that exists between the study of complex egalitarian societies by anarchist archaeologists such as Flexner, Sanger and Borck, and the critique of modern industrial state power in the classical anarchist tradition. Because it has been focussed on the modern military-industrial state, anarchist writing can - somewhat counterintuitively - make state power seem much more imposing than it was in fact for much of history. Medieval history thus provides a good avenue through which a more historically-informed conception of the state could enter anarchist discussion, thereby encouraging an empirically-grounded hope in the possibility of alternative futures.

Neither historians nor anarchists can afford the luxury of failing to elucidate the variety of experiences of the state, and anarchists should neither accept romantic visions of the Middle Ages as 'that great period of federalism', 58 nor restrict their analysis to 'nonstate' spaces such as Scott's Zomia or present-day attempts to form autonomous communities. Indeed for historians, the main drawback of Scott's Zomia model is that it imagines state and non-state regions as a 'neat binary' with nothing in between, whereas to study medieval societies is to find oneself thinking about people who had complex and varied relationships to states. ${ }^{59}$ Scott's approach reflects a tendency in anarchist thinking to reify 'the state' across time and space, looking for the moments when non-state societies became states, in a somewhat unrealistic zero-sum game. This model also tends to imagine states as designed and imposed, in contrast to non-state societies, which are presented as organic and natural. This is yet another hangover from traditional constitutional historical thinking, and indeed from early anarchist historical writings such as those of Kropotkin and Rocker, which tended to share the 
If you wish to cite this pre-publication paper, please use the following format: lan Forrest, 'Medieval History and Anarchist Studies', forthcoming in Anarchist Studies, 29:1 (Spring 2021).

liberal constitutional view of states designed and created by elites. Some anarchists have yet to shed this view, even though - as discussed above - other anarchist scholars have thought hard about the active social processes by which egalitarianism is sustained. A fuller understanding of state growth needs to take more account of the organic, often symbiotic, processes by which it occurred, while integrating ideas about the suppression of hierarchy.

We need complex histories of people living alongside and in cahoots with the state, negotiating their agency in relation to its power, keeping it at bay while simultaneously exploiting its opportunities, and surviving in the gaps created by competition between the state's would-be collaborators: people 'staying with the trouble' to adopt Donna Haraway's determined phrase. ${ }^{60}$ Just as Sanger has written that archaeologists ought to avoid homogenising 'simple' societies, medieval historians are disinclined to homogenise the experience of people who lived in times and places where growing central institutional power collided with strong local institutions. There is therefore potential for anarchists, in conversation with medieval historians and archaeologists, to develop and critique the 'Zomia' thesis with reference to a broader range of historical experience. None of this need fall into the trap of using an 'anarchist heuristic' to normalise liberal concepts of the nation state (as benign, distant and light touch), ${ }^{61}$ so long as the aim of engagement is to deepen understanding of how states have affected people's lives, and the complex processes by which state power waxes and wanes. 
If you wish to cite this pre-publication paper, please use the following format: lan Forrest, 'Medieval History and Anarchist Studies', forthcoming in Anarchist Studies, 29:1 (Spring 2021).

Finally, in not engaging with research into pre-modern history, anarchists risk romanticising daily life in ungoverned and less-governed societies. The shadow of Kropotkin's misconceptions about popular assemblies in the Middle Ages is indeed a long one, obscuring what anarchists today could really learn from the far more complex play of politics in a time when 'community' involved hierarchy and domination alongside a degree of autonomy and cooperation. There is a lot of research into the inequalities, especially gender inequalities, of the communal institutions and more-orless autonomous groups that existed in the Middle Ages, just as anthropologists and archaeologists have long pointed to the violence and domination within many autonomous and so-called egalitarian societies. If greater numbers of anarchist academics were to engage openly and critically with this historical research a more sophisticated conception of really-existing autonomy would surely emerge.

\section{A possible agenda for an anarchist history}

I am rather fond of a taking out of context a line written by the liberal philosopher Bernard Williams - 'at a certain point philosophy needs to make way for history'62 - and for anarchists there is no time like the present: it could be liberating to turn from political theory to lived history. Thinking with the evidence of past lived realities is emancipatory - it allows the historian or archaeologist to experiment in both the scientific and the playfully curious senses - but also necessary. Past experience provides insights and lessons that cannot easily be rejected in favour of the logical coherence of theory or a desire to trace the progress of a disembodied idea context-free 
If you wish to cite this pre-publication paper, please use the following format: lan Forrest, 'Medieval History and Anarchist Studies', forthcoming in Anarchist Studies, 29:1 (Spring 2021).

through different historical epochs. Historians believe that context matters. The questions that anarchist historians might ask ought therefore to be empirical, but never straightforwardly so. The answers to each of the following could be argued over at length. Historians do not provide factual answers, but they do deal in the reality of lived experience, rather than layering theory upon theory, their empiricism lying in a search for knowledge of how things have really been, rather than in a misplaced confidence in the finality of any such knowledge.

- When and how does the capacity for domination increase or its effect intensify?

- What conjunctions of elite power-grabbing, co-option of local agents, economic fluctuations, social stratification, and ideological or cultural change are associated with increases and decreases in the levels of domination in a society?

- What are the lines of causation associated with these conjunctions?

- In what ways have states and institutions contributed to rising inequality and loss of freedom?

- Over what timescales have these conjunctions produced change in the levels of domination, autonomy, and cooperation?

- What is the range in experiences of autonomy and cooperation, and in what circumstances have they flourished?

- What social processes, ideas and attitudes have effectively suppressed hierarchy and inequality? How consciously have they been deployed to these ends?

- Has cooperation and autonomy only ever been achieved by limiting its benefits to a defined group? Under what forms of domination, if any, has such 
If you wish to cite this pre-publication paper, please use the following format: lan Forrest, 'Medieval History and Anarchist Studies', forthcoming in Anarchist Studies, 29:1 (Spring 2021).

constrained autonomy flourished? Given that autonomy and domination are not the exclusive alternatives in a zero-sum game, whose autonomy and whose domination have had a historic relationship?

- What has been the relationship between 'state growth' and conscious efforts on the part of ordinary people either to contribute to or reduce its powers (i.e. willing collaboration and conscious resistance)?

- When, and why, have people migrated into and out of the orbit of state power?

These questions are just suggestions, intended to stimulate debate. Considering the many other perspectives that historians and anarchists have, there is great potential for productive dialogue. Medieval historians willing to enter into this dialogue will find anarchist perspectives to be radical inflections of some already-current ideas in their field of study, while anarchists will find historians to be, generally speaking, people by inclination unfussy in their adoption of theory and willing to try out ideas that produce interesting results. History is not political science; historians are averse to flattening generalisations and at home with the multiplication of diversity and difference, medievalists somewhat more so than most; many are used to thinking about history at a human scale and there are long traditions of feminist and Marxist history writing that seek to recover the experiences of people who don't fit easily into the grand narratives of state building, modernisation, and globalisation. To me these characteristics seem to chime with anarchist instincts in many ways, perhaps making for happy collaboration if both anarchists and medievalists were to cultivate their desire to learn from other ways of thinking about the world.

If you wish to cite this pre-publication paper, please use the following format: lan Forrest, 'Medieval History and Anarchist Studies', forthcoming in Anarchist Studies, 29:1 (Spring 2021). 
If you wish to cite this pre-publication paper, please use the following format: lan Forrest, 'Medieval History and Anarchist Studies', forthcoming in Anarchist Studies, 29:1 (Spring 2021).

$* * * * * * * * * * * * * * * * *$

If you wish to cite this pre-publication paper, please use the following format: lan Forrest, 'Medieval History and Anarchist Studies', forthcoming in Anarchist Studies, 29:1 (Spring 2021). 
If you wish to cite this pre-publication paper, please use the following format: lan Forrest, 'Medieval History and Anarchist Studies', forthcoming in Anarchist Studies, 29:1 (Spring 2021).

1 Peter Alekseevich Kropotkin, Mutual Aid: A Factor of Evolution (London, 1902); Rudolf Rocker, Nationalism and Culture, trans. Ray E. Chase (St Paul, Minn., 1978).

2 George Woodcock, Anarchism (Harmondsworth, 1962), pp. 38-40; Peter Marshall, Demanding the Impossible: A History of Anarchism (London, 1992), pp. 88-95.

3 Peter Gelderloos, Worshipping Power: An Anarchist View of Early State Formation (Chico, CA, 2016); David Graeber, Debt: The First 5000 Years (New York, 2011).

${ }^{4}$ Matthew S. Adams, 'The Possibilities of Anarchist History: Rethinking the Canon and Writing History', in Ruth Kinna and Süreyyya Evren (ed.), Blasting the Canon, Anarchist Developments in Cultural Studies, 1 (2013), pp. 33-63; Sho Konishi, Anarchist Modernity: Cooperatism and Japanese-Russian Intellectual Relations in Modern Japan (Cambridge, Mass., 2013); Ruth Kinna, Kropotkin: Reviewing the Classical Anarchist Tradition (Edinburgh, 2016).

${ }^{5}$ For recent discussions of trends in Marxist and feminist history writing see Chris Wickham (ed.), Marxist History Writing for the Twenty-First Century (Oxford, 2007), and Judith Bennett, History Matters: Patriarchy and the Challenge of Feminism (Manchester, 2006); Bennett in fact urges feminists to reconnect with historical study, noting a shift away from the historicallyinformed feminism of the 1960s and '70s towards a more present-minded theory and activism in the 2000s.

${ }^{6}$ Bennett, History Matters, p. 60.

${ }^{7}$ David Graeber, Direct Action: An Ethnography (Oakland, CA, 2009), p. 211.

${ }^{8}$ Lewis Borck and Matthew C. Sanger, 'An Introduction to Anarchism in Archaeology', Society for American Archaeology: Archaeological Record, 17 (2017), p. 9.

If you wish to cite this pre-publication paper, please use the following format: lan Forrest, 'Medieval History and Anarchist Studies', forthcoming in Anarchist Studies, 29:1 (Spring 2021). 
If you wish to cite this pre-publication paper, please use the following format: lan Forrest, 'Medieval History and Anarchist Studies', forthcoming in Anarchist Studies, 29:1 (Spring 2021).

${ }_{9}^{9}$ Alan Carter, 'Analytical Anarchism: Some Conceptual Foundations', Political Theory, 28:2 (2001); for discussion see Stuart Ingham, 'Analytical Anarchism? A Critique of Alan Carter's Anarchist Theory of History', Class and Capital, 40:1 (2016).

${ }^{10}$ James C. Scott, The Art of Not Being Governed: An Anarchist History of Upland Southeast Asia (New Haven, Conn., 2009); Pierre Clastres, Society against the State: Essays in Political Anthropology (New York, 1989; first published as Société contre l'état 1974); Willem van Schendel, 'Geographies of Knowing, Geographies of Ignorance: Jumping Scale in Southeast Asia', Environment and Planning D: Society and Space, 20 (2002), pp. 647-68.

11 William G. Clarence-Smith, 'Editorial Note - Zomia and Beyond', Journal of Global History, 5 (2010), p. 185.

${ }^{12}$ James C. Scott, Weapons of the Weak: Everyday Forms of Peasant Resistance (New Haven, Conn., 1985), and idem, Domination and the Arts of Resistance: Hidden Transcripts (New Haven, Conn., 1990). The influence of these two books in medieval studies has been remarkably wide: for example, on 'hidden transcripts' see Peter L. Larson, Conflict and Compromise in the LateMedieval Countryside: Lords and Peasants in Durham, 1349-1400 (New York, 2006), p. 45, and Patricia Ewick and Susan S. Silbey, 'Conformity, Contestation, and Resistance: An Account of Legal Consciousness', New England Law Review, 26 (1992); on 'weapons of the weak' see James Given, Inquisition and Medieval Society: Power, Discipline and Resistance in Languedoc (Ithaca, NY, 1997), p. 109, as to whether resistance to inquisition can be understood within this framework, and Carol Lansing, 'Conflicts over Gender in Civic Courts', in Judith Bennett and Ruth Karras (eds.), The Oxford Handbook of Women and Gender in Medieval Europe (Oxford, 2015), pp. 123-24, applying Scott's model to victim responses to rape.

${ }^{13}$ A recent workshop involving medieval historians and archaeologists from Europe and Japan examined the viability of 'Medieval Zomias: Stateless Spaces in the Global Middle Ages' as an

If you wish to cite this pre-publication paper, please use the following format: lan Forrest, 'Medieval History and Anarchist Studies', forthcoming in Anarchist Studies, 29:1 (Spring 2021). 
If you wish to cite this pre-publication paper, please use the following format: lan Forrest, 'Medieval History and Anarchist Studies', forthcoming in Anarchist Studies, 29:1 (Spring 2021).

object of research: https://global.history.ox.ac.uk/event/conference-medieval-zomiasstateless-spaces-global-middle-ages

${ }^{14}$ Graeber, Debt: The First 5000 Years; an account of the conference 'Debt: 5000 Years and Counting' is available in Ilya Afanasyev, Nicholas Evans and Nicholas Matheou, 'Doing conferences differently' (https://www.versobooks.com/blogs/4028-doing-conferencesdifferently).

${ }^{15}$ Fragments of an Anarchist Anthropology (Chicago, 2004).

16 Graeber, Debt, p. 391.

17 https://savageminds.org/2016/10/31/foundations-of-an-anarchist-archaeology-acommunity-manifesto/

${ }^{18}$ James L. Flexner, 'The Historical Archaeology of States and Non-States: Anarchist Perspectives from Hawai'i and Vanuatu', Journal of Pacific Archaeology, 5 (2014), pp. 83-4, argues that historians are the hopeless captives of the institutional records they use, which is unduly harsh, but contains more than a grain of truth.

${ }^{19}$ Matthew Sanger, 'Anarchic Theory and the Study of Hunter-Gatherers', SAA Archaeological Record, 17 (2017), pp. 39-44; Flexner, 'Historical Archaeology of States and Non-States'; Graeber, Fragments, pp. 24-6.

20 Theresa Kintz, 'An Anarchist Archaeology for the Anthropocene: A Manifesto', SAA Archaeological Record, 17 (2017), pp. 33-38; Amanda Power, 'Medieval Histories of the Anthropocene', unpublished paper delivered at the German Historical Institute, London, 29 May 2018.

${ }^{21}$ Peter Thonemann, 'Phrygia: An Anarchist History, 950BCE-100CE', in idem (ed.), Roman Phrygia: Culture and Society (Cambridge, 2013), p. 3.

If you wish to cite this pre-publication paper, please use the following format: lan Forrest, 'Medieval History and Anarchist Studies', forthcoming in Anarchist Studies, 29:1 (Spring 2021). 
If you wish to cite this pre-publication paper, please use the following format: lan Forrest, 'Medieval History and Anarchist Studies', forthcoming in Anarchist Studies, 29:1 (Spring 2021).

22 Thonemann, 'Phrygia: An Anarchist History', p. 15, points out that besides making themselves immune from Persian tribute-raising, the Phrygians also became more vulnerable to slaveraiding from more powerful eastern Mediterranean polities.

${ }^{23}$ On heterarchy see Carole L. Crumley, 'Heterarchy and the Analysis of Complex Societies', Archaeological Papers of the American Anthropological Association, 6 (1995), pp. 1-15; on acephalous networks see Harold Barclay, 'Segmental Acephalous Network Systems: Alternatives to Centralised Bureaucracy', The Raven, 7 (1989), pp. 2017-24; on counterpower see Graeber, Fragments of an Anarchist Anthropology, pp. 24-37, and Clastres, Society Against the State, pp. 146-7; on consensus see Uri Gordon, Anarchy Alive! Anti-Authoritarian Politics from Practice and Theory (London, 2008), pp. 65-71.

${ }^{24}$ For example John H. Arnold, 'The Historian as Inquisitor: The Ethics of Interrogating Subaltern Voices', Rethinking History, 2 (1998), pp. 379-86.

${ }_{25}$ Paul Lunde and Caroline Stone (eds.), Ibn Fadlan and the Land of Darkness: Arab Travellers in the Far North (London, 2012); Ibn Khaldun, The Muqaddimah: An Introduction to History, trans. Franz Rosenthal, abridged N. J. Dawood (Princeton, NJ, 1967).

${ }^{26}$ For general discussion see Geraldine Heng, The Invention of Race in the European Middle Ages (Cambridge, 2018).

27 Thonemann, 'Phrygia: An Anarchist History', pp. 11-14.

${ }^{28}$ Roderick J. McIntosh, Ancient Middle Niger: Urbanism and the Self-Organizing Landscape (Cambridge, 2005).

${ }^{29}$ Mike Pearson, Niall Sharples, and Jacquie Mulville, 'Brochs and Iron Age Society: A Reappraisal', Antiquity, 70 (1996), pp. 57-67; on tents and archaeology see Timothy Insoll, The Archaeology of Islam (Oxford, 1999), pp. 72-4.

If you wish to cite this pre-publication paper, please use the following format: lan Forrest, 'Medieval History and Anarchist Studies', forthcoming in Anarchist Studies, 29:1 (Spring 2021). 
If you wish to cite this pre-publication paper, please use the following format: lan Forrest, 'Medieval History and Anarchist Studies', forthcoming in Anarchist Studies, 29:1 (Spring 2021).

${ }^{30}$ For one set of examples amongst many see The Register of John Waltham Bishop of Salisbury 1388-1395, ed. T.C.B. Timmins (Woodbridge, 1994), pp. 212-3, where those absent from church are explicitly said to be attending markets instead.

${ }^{31}$ Richard Sosis, ‘Does Religion Promote Trust? The Role of Signalling, Reputation, and Punishment', Interdisciplinary Journal of Research on Religion, 1 (2005), pp. 1-30, at p. 16. ${ }^{32}$ Fernand Braudel, The Mediterranean and the Mediterranean World in the Age of Philip II, 2 vols., trans. Siân Reynolds (London: Collins, 1972-3), I, p. 38; for discussion see Benoît Cursente, 'Les montagnes des médiévistes', in Montagnes médiévales (Paris, 2004), pp. 419-21.

${ }^{33}$ Ian Forrest, Trustworthy Men: How Inequality and Faith Made the Medieval Church (Princeton, NJ, 2018), pp. 209-13, examines the ways in which upland, heath, and wood-pasture landscapes in late medieval England were less amenable to church power than neighbouring lowland regions.

${ }^{34}$ Carole L. Crumley and Alf Hornberg (eds.), The World System and the Earth System: Global Socioenvironmental Change and Sustainability since the Neolithic (Walnut Creek, CA, 2007). 35 Bruce M. S. Campbell, The Great Transition: Climate, Disease and Society in the Late Medieval World (Cambridge, 2016).

36 Gordon, Anarchy Alive!, pp. 31-4.

37 On intersectionality see Kimberlé Crenshaw, 'Demarginalizing the Intersection of Race and Sex: A Black Feminist Critique of Antidiscrimination Doctrine, Feminist Theory and Antiracist Politics', The University of Chicago Legal Forum, 140 (1989), pp. 139-167; for an anarchist critique see AngryWorkersWorld, ‘Class, Racism and Women's Oppression: Critical Thoughts on Intersectionality Theory': https://libcom.org/blog/class-racism-women-s-oppression-criticalthoughts-intersectionality-theory-19062019.

38 Gerda Lerner, The Majority Finds Its Past: Placing Women in History (New York, 1979), p. 180.

If you wish to cite this pre-publication paper, please use the following format: lan Forrest, 'Medieval History and Anarchist Studies', forthcoming in Anarchist Studies, 29:1 (Spring 2021). 
If you wish to cite this pre-publication paper, please use the following format: lan Forrest, 'Medieval History and Anarchist Studies', forthcoming in Anarchist Studies, 29:1 (Spring 2021).

39 Bennett, History Matters, p. 28.

${ }^{40}$ See for example P.J.P. Goldberg, Communal Discord, Child Abduction and Rape in the Later Middle Ages (Basingstoke, 2008); Ruth M. Karras, Common Women: Prostitution and Sexuality in Medieval England (Oxford, 1996); Sharon Farmer, ‘The Beggar's Body: Intersections of Gender and Status in High Medieval Paris', in Sharon Farmer and Barbara Rosenwein (eds.), Monks and Nuns, Saints and Outcasts (Ithaca, NY, 2000), pp. 153-71.

${ }^{41}$ Rodney Hilton, Bond Men Made Free: Medieval Peasant Movements and the English Rising of 1381 (London, 1973); Eric Hobsbawm, Primitive Rebels: Studies in Archaic Forms of Social Movement in the $19^{\text {th }}$ and $20^{\text {th }}$ Centuries (Manchester, 1959); Boris Porchnev, Les soulèvements populaires en France de 1623 á 1648 (Paris, 1963); Edward P. Thompson, The Making of the English Working Class (London, 1963).

${ }^{42}$ Chris Dyer, 'The Rising of 1381 in Suffolk: Its Origins and Participants', in T. H. Aston and R. H. Hilton (eds.), The English Rising of 1381 (Cambridge, 1984).

${ }^{43}$ Gordon, Anarchy Alive!, p. 55; Graeber, Direct Action, p. 533; Victor Liebermann's review of The Art of Not Being Governed similarly claims that Scott 'in his preoccupation with state domination ... conflates official impositions with popular conflicts': 'A Zone of Refuge in Southeast Asia? Reconceptualizing Interior Spaces', Journal of Global History, 5 (2010), p. 341. ${ }^{44}$ Gordon, Anarchy Alive!, pp. 40-3.

45 Steven Justice, 'Religious Dissent, Social Revolt and “Ideology”', in Christopher Dyer et al (eds.), Rodney Hilton's Middle Ages (Oxford, 2007).

${ }^{46}$ Rocker, Nationalism and Culture, p. 39; Jan Philipp Reemtsma, Trust and Violence: An Essay on a Modern Relationship (Princeton, NJ, 2012), p. 8.

If you wish to cite this pre-publication paper, please use the following format: lan Forrest, 'Medieval History and Anarchist Studies', forthcoming in Anarchist Studies, 29:1 (Spring 2021). 
If you wish to cite this pre-publication paper, please use the following format: lan Forrest, 'Medieval History and Anarchist Studies', forthcoming in Anarchist Studies, 29:1 (Spring 2021).

47 The literature is large, but on heresy and inquisition see in particular Given, Inquisition and Medieval Society; on anti-Jewish action by states Robin R. Mundhill, England's Jewish Solution, 1262-1290: Experiment and Expulsion (Cambridge, 1998).

48 James C. Scott, Two Cheers for Anarchism: Six Easy Pieces on Autonomy, Dignity, and Meaningful Work and Play (Princeton, NJ, 2012), p. 141.

${ }^{49}$ Peter Blickle, From the Communal Reformation to the Revolution of the Common Man (Leiden, 1998); James Masschaele, Jury, State, and Society in Medieval England (New York, 2008). 50 Forrest, Trustworthy Men.

${ }^{51}$ Stuart Rathbone, 'Anarchist Literature and the Development of Anarchist CounterArchaeologies', World Archaeology, 49 (2017), p. 299.

52 Sanger, 'Anarchic Theory and the Study of Hunter-Gatherers'; Lewis Borck and Erik Simpson, 'Identity is an Infinite Now: Being Instead of Becoming Gallina', KIVA: Journal of Southwestern Anthropology and History, 83 (2017); Carlos Maldonado and Natalie Mezza-Garcia, 'Anarchy and Complexity', Emergence: Complexity and Organisation (2016), compare anarchic social processes to complexity theory in the physical and natural sciences, noting that institutions in general artificially restrict the natural tendency towards self-organization and self-control that human social systems would present in the absence of these coercive institutions' (emphasis added).

${ }^{53}$ Ian Forrest, 'Power and the People in Thirteenth-Century England', in Janet Burton, Phillipp Schofield and Björn Weiler (eds.), Authority and Resistance in the Age of Magna Carta (Woodbridge, 2015).

${ }^{54}$ Flexner, 'The Historical Archaeology of States and Non-States', p. 83.

If you wish to cite this pre-publication paper, please use the following format: lan Forrest, 'Medieval History and Anarchist Studies', forthcoming in Anarchist Studies, 29:1 (Spring 2021). 
If you wish to cite this pre-publication paper, please use the following format: lan Forrest, 'Medieval History and Anarchist Studies', forthcoming in Anarchist Studies, 29:1 (Spring 2021).

55 Tom Bisson, The Crisis of the Twelfth Century: Power, Lordship, and the Origins of European Government (Princeton, NJ, 2009), pp. 321, 369.

56 Carol Symes, 'When We Talk About Modernity', American Historical Review, 116 (2011).

${ }^{57}$ Catherine Holmes and Naomi Standen, 'Introduction', in idem (eds.), The Global Middle Ages, Past and Present supplement (2018).

${ }^{58}$ Rocker, Nationalism and Culture, p. 91.

${ }^{59}$ Shalini Randeria, 'Opting for Statelessness', European Journal of Sociology, 51 (2010), p. 466.

60 Donna Haraway, Staying with the Trouble: Making Kin in the Cthulucene (Duke University Press, 2016).

${ }^{61}$ Shelagh Roxburgh, 'Against Soft Anarchism: Challenging Liberal Cooptations of Anarchism in International Relations Theory', Anarchist Studies, 26 (2018).

62 Bernard Williams, Truth and Truthfulness: An Essay in Genealogy (Princeton, NJ, 2002), p. 93.

If you wish to cite this pre-publication paper, please use the following format: lan Forrest, 'Medieval History and Anarchist Studies', forthcoming in Anarchist Studies, 29:1 (Spring 2021). 